\title{
Blood micronutrient, oxidative stress, and viral load in patients with chronic hepatitis $\mathrm{C}$
}

\author{
Wang-Sheng Ko, Chih-Hung Guo, Maw-Sheng Yeh, Li-Yun Lin, Guoo-Shyng W. Hsu, Pei-Chung Chen, Mei-Ching Luo, \\ Chia-Yeh Lin
}

\author{
Wang-Sheng Ko, Department of Food and Nutrition, Hung Kuang \\ University; Department of Internal Medicine, Kuang-Tien General \\ Hospital, Taichung 433, Taiwan, China \\ Chih-Hung Guo, Maw-Sheng Yeh, Li-Yun Lin, Mei-Ching Luo, \\ Chia-Yeh Lin, Department of Food and Nutrition, Hung Kuang \\ University, Taichung 433, Taiwan, China \\ Guoo-Shyng W. Hsu, Department of Nutrition and Food Sciences, \\ Fu Jen University, Taipei 242, Taiwan, China \\ Pei-Chung Chen, Department of Biotechnology, Hung Kuang \\ University, Taichung 433, Taiwan, China \\ Supported by the Kuang-Tien General Hospital, Taichung, Taiwan, \\ China \\ Co-first-authors: Wang-Sheng Ko and Chih-Hung Guo \\ Co-correspondents: Wang-Sheng Ko \\ Correspondence to: Chih-Hung Guo, Department of Food and \\ Nutrition, Hung Kuang University, Taichung 433, Taiwan, \\ China. eillyguo@sunrise.hk.edu.tw \\ Telephone: +886-42631-8652-5037 Fax: +886-42631-9176 \\ Received: 2004-10-10 Accepted: 2004-12-23
}

\begin{abstract}
AIM: To assess the extent of micronutrient and oxidative stress in blood and to examine their linkages with viral loads in chronic hepatitis $\mathrm{C}$ patients.

METHODS: Hepatitis C virus (HCV)-RNA levels were quantified in the serum from 37 previously untreated patients with chronic hepatitis $C$. The plasma and erythrocyte micronutrients (zinc, selenium, copper, and iron) were estimated, and malondialdehyde (MDA) contents were determined as a marker to detect oxidative stress. Antioxidant enzymes, superoxide dismutase (SOD), glutathione peroxidase (GPX) and glutathione reductase (GR) activities in blood were also measured. The control group contained 31 healthy volunteers.
\end{abstract}

RESULTS: The contents of zinc (Zn), and selenium (Se) in plasma and erythrocytes were significantly lower in hepatitis $\mathrm{C}$ patients than in the controls. On the contrary, copper $(\mathrm{Cu})$ levels were significantly higher. Furthermore, plasma and erythrocyte MDA levels, and the SOD and GR activities in erythrocytes significantly increased in hepatitis $C$ patients compared to the controls. However, the plasma GPX activity in patients was markedly lower. Plasma Se $(r=-0.730, P<0.05), \mathrm{Cu}(r=0.635)$, and GPX $(r=-0.675)$ demonstrated correlations with HCV-RNA loads. Significant correlation coefficients were also observed between HCV-RNA levels and erythrocyte Zn $(r=-0.403)$, Se $(r=-0.544), \mathrm{Cu}(r=0.701)$ and MDA $(r=0.629)$ and GR $(r=0.441)$.
CONCLUSION: The levels of $\mathrm{Zn}, \mathrm{Se}, \mathrm{Cu}$, and oxidative stress (MDA), as well as related anti-oxidative enzymes (GR and GPX) in blood have important impact on the viral factors in chronic hepatitis $\mathrm{C}$. The distribution of these parameters might be significant biomarkers for HCV.

(c) 2005 The WJG Press and Elsevier Inc. All rights reserved.

Key words: Micronutrient; Oxidative stress; Viral load; Plasma and erythrocytes; Hepatitis C

Ko WS, Guo CH, Yeh MS, Lin LY, Hsu GSW, Chen PC, Luo $M C$, Lin CY. Blood micronutrient, oxidative stress, and viral load in patients with chronic hepatitis C. World J Gastroenterol 2005; 11(30): 4697-4702

http://www.wjgnet.com/1007-9327/11/4697.asp

\section{INTRODUCTION}

Essential micronutrients are involved in many metabolic pathways in the liver, such as enzymatic functions and protein synthesis, oxidative damage and anti-oxidant defense, immunological competence, interferon therapy response regulations, and alterations of the virus genomes ${ }^{[1-5]}$. Reactive oxygen species (ROS) have also been implicated in a number of hepatic pathologies in exacerbating liver diseases ${ }^{[6-10]}$. The oxidant production associated with immune reactions against viral hepatitis leads to the formation of hepatocellular carcinoma $(\mathrm{HCC})^{[8]}$. Therefore, the changes in micronutrients and their demolishing effects against oxidative stress are factors for viral hepatitis pathogenesis.

$\mathrm{HCV}$ is a major cause of chronic liver disease. HCV infection frequently leads to chronic hepatitis with increasing risk of developing liver cirrhosis and HCC. Interferon with or without ribavirin is the only drug with proven efficacy in treating chronic HCV infections ${ }^{[11-13]}$. Unfortunately, these therapeutic models maintain the rate of sustained virologic response (SVR) to approximately $10-40 \%{ }^{[1416]}$. The effective advancement in the antiviral treatments against chronic hepatitis $C$ is necessary.

There are several factors that attribute to the failure in achieving a SVR for the majority of patients ${ }^{[17-19]}$. Hepatic iron deposit has been identified as one of these factors ${ }^{[20-23]}$. Iron depletion and zinc supplementation ${ }^{[24,25]}$ may improve the response of chronic hepatitis $\mathrm{C}$ patients to interferon treatment. Moreover, viral factors may affect the outcome of the therapy. Zhang et al. ${ }^{[26]}$, indicated that seleniumdependent glutathione peroxidase (GPX) modules are 
encoded in the RNA viruses. The presence of zinc ion also decreases the HIV-1 reverse transcriptase activity ${ }^{[2]}$. It is conceivable that the micronutrient status may affect the HCV load and viral replication, leading to significant changes in reported SVR rates. However, there is limited information about the distribution of micronutrients and their effects on viral production.

Our present study aimed to examine the levels of micronutrients (zinc, copper, iron, selenium), and malondialdehyde (MDA) which is an indirect marker for oxidative stress in blood. Moreover, superoxide dismutase (SOD), glutathione reductase (GR) and GPX activities were assessed. In addition, the relationships among these parameters and HCV-RNA levels in patients with chronic hepatitis $C$ were investigated.

\section{MATERIALS AND METHODS}

\section{Subjects}

This study contained 33 patients with chronic hepatitis C including 20 men and 13 women (from 2002 to 2003). The mean age of the patients was $49.5 \pm 2.4$ years. All patients underwent serological and biochemical analyses. Diagnosis of chronic hepatitis $\mathrm{C}$ was based on elevated serum alanine aminotransferase levels for at least $6 \mathrm{mo}$, and consistent detection of serum HCV-RNA. All patients were negative for hepatitis B surface antigen and HIV, and none had liver cirrhosis or renal disease.

A control group of 31 healthy volunteers $(17$ men and 14 women) was recruited from blood donors aged $43.2 \pm 1.7$ years. They underwent a routine medical examination prior to the blood collection.

\section{Biochemical determinations and HCV-RNA analysis}

Venous blood samples were collected from patients prior to treatment. Erythrocytes were pelleted by centrifugation and washed thrice with cold isotonic saline. The plasma and erythrocyte zinc $(\mathrm{Zn})$, copper $(\mathrm{Cu})$, and iron $(\mathrm{Fe})$ levels were determined by flame atomic absorption spectrophotometry (932 plus, GBC, Australia) as previously described ${ }^{[28]}$. The accessory hydride formation system (HG3000), also from GBC, was used for determining selenium (Se) concentrations. All samples were analyzed in triplicate. Serum "secondgeneration" reference materials (Seronorm ${ }^{\text {TM }}$ Trace Elements Serum) were purchased from Nycomed, Oslo, Norway.

Thiobarbituric acid substances reacted with products of lipid peroxidation, mainly MDA, producing a pink color compound that could be measured at $535 \mathrm{~nm}$. Following the protocol in Richard et al. ${ }^{[29]}$, thiobarbituric acid levels were determined in plasma and erythrocytes of patients and controls. Results were expressed as nanomoles of MDA per milliliter in plasma and as nanomoles of MDA per gram protein in erythrocytes. Protein concentration was determined using the Coomassie protein assay (Pierce, Rockford, IL, USA) with bovine serum albumin as the standard.

Erythrocyte SOD and GPX activities in plasma were determined with RANSOD kits (Randox, San Diego) and Cayman GPx assay kits (Cayman Chemical, USA) respectively. All values were expressed as units per gram hemoglobin or units per milliliter. One unit of SOD was defined as the amount of enzyme necessary to produce $50 \%$ inhibition in the $p$-iodonitrotetrazolium reduction rate. The activity of GR in erythrocytes was also measured at $340 \mathrm{~nm}$ using the commercial kits (GR340, OxisResearch). One GR activity unit was defined as the amount of enzyme catalyzing the reduction of $1 \mathrm{mmoL}$ of GSSG.

Additionally, viral RNA was detected and quantitative HCV-RNA was determined by Amplicor (Roche Molecular Diagnostics) and expressed as the log of copies of RNA per milliliter. RNA was extracted from serum samples following the manufacturer's instructions (QIAamp viral RNA kit from Qiagen Inc.). This assay had a lower limit of 100 copies/mL.

\section{Statistical analysis}

Data were expressed as mean \pm SE. Significant differences in variables between two groups were tested by Student's t-test. $P<0.05$ was considered statistically significant. Linear regressions were used to analyze the correlation among variables.

\section{RESULTS}

\section{Blood micronutrient levels}

Table 1 shows the values of specific micronutrients in plasma of chronic hepatitis $C$ patients and healthy subjects. There was a significant decrease in $\mathrm{Zn}$ and Se and a statistical increase in $\mathrm{Cu}$ concentrations of the patients $(P<0.05)$. However, plasma Fe levels revealed no significant difference $(P>0.05)$.

The erythrocyte concentration of $\mathrm{Cu}$ in the patients was significantly higher than that in the healthy controls, and the Fe concentrations were not significantly different between two groups. Furthermore, Se and Zn levels were significantly lower in erythrocytes of the patients (Table 2).

Table 1 Plasma concentrations of $\mathrm{Zn}, \mathrm{Cu}, \mathrm{Fe}$, and $\mathrm{Se}$ in patients with chronic hepatitis $\mathrm{C}$ and healthy controls (mean $\pm \mathrm{SE}$ )

\begin{tabular}{lcccc}
\hline \multirow{2}{*}{ Groups } & \multicolumn{4}{c}{ Plasma } \\
\cline { 2 - 5 } & $\mathrm{Zn}(\mathrm{mg} / \mathrm{L})$ & $\mathrm{Cu}(\mathrm{mg} / \mathrm{L})$ & $\mathrm{Fe}(\mathrm{mg} / \mathrm{L})$ & $\mathrm{Se}(\mu \mathrm{g} / \mathrm{L})$ \\
\hline Patients & $0.13 \pm 0.01^{\mathrm{a}}$ & $1.68 \pm 0.08^{\mathrm{a}}$ & $0.56 \pm 0.04$ & $159.12 \pm 5.30^{\mathrm{a}}$ \\
Healthy controls & $0.55 \pm 0.06$ & $0.53 \pm 0.03$ & $0.57 \pm 0.03$ & $216.69 \pm 7.44$ \\
\hline
\end{tabular}

${ }^{a} P<0.05 v$ s healthy controls.

Table 2 Erythrocyte levels of $\mathrm{Zn}, \mathrm{Cu}, \mathrm{Fe}$, and Se in patients with chronic hepatitis $C$ and healthy controls (mean $\pm S E$ )

\begin{tabular}{lcccr}
\hline \multirow{2}{*}{ Groups } & \multicolumn{4}{c}{ Erythrocytes } \\
\cline { 2 - 5 } & $\mathrm{Zn}(\mathrm{mg} / \mathrm{L})$ & $\mathrm{Cu}(\mathrm{mg} / \mathrm{L})$ & $\mathrm{Fe}(\mathrm{mg} / \mathrm{L})$ & $\mathrm{Se}(\mu \mathrm{g} / \mathrm{L})$ \\
\hline Patients & $0.79 \pm 0.05^{\mathrm{a}}$ & $0.52 \pm 0.05^{\mathrm{a}}$ & $1369.8 \pm 88.6$ & $55.09 \pm 3.79^{\mathrm{a}}$ \\
Healthy controls & $1.40 \pm 0.10$ & $0.09 \pm 0.01$ & $1075.9 \pm 96.7$ & $139.08 \pm 5.76$
\end{tabular}

a $P<0.05$ vs healthy controls

\section{Evidence of oxidative stress}

Table 3 summarizes the values of parameters related to oxidative stress. Erythrocyte and plasma MDA increased 
Table 3 MDA levels, SOD, GR, and GPX activities in patients with chronic hepatitis C and healthy controls (mean \pm SE)

\begin{tabular}{|c|c|c|c|c|c|}
\hline \multirow{3}{*}{ Group } & \multicolumn{5}{|c|}{ Parameters $^{1}$} \\
\hline & \multicolumn{2}{|c|}{ MDA } & \multirow[t]{2}{*}{$\mathrm{SOD}(\mathrm{U} / \mathrm{g} \mathrm{Hb})$} & \multirow[t]{2}{*}{$\mathrm{GR}(\mathrm{mU} / \mathrm{g} \mathrm{Hb})$} & \multirow{2}{*}{$\begin{array}{c}\mathrm{GPX} \\
{[\mathrm{nmol} /(\mathrm{min} \cdot \mathrm{mL})]}\end{array}$} \\
\hline & Plasma (nmol/mL) & $\mathrm{RBC}$ (nmol/g protein) & & & \\
\hline Patients & $0.41 \pm 0.02^{\mathrm{a}}$ & $0.33 \pm 0.02^{\mathrm{a}}$ & $17.95 \pm 0.51^{\mathrm{a}}$ & $40.10 \pm 2.48^{\mathrm{a}}$ & $38.95 \pm 1.99^{\mathrm{a}}$ \\
\hline Healthy controls & $0.15 \pm 0.01$ & $0.19 \pm 0.02$ & $15.24 \pm 0.45$ & $30.15 \pm 2.69$ & $51.26 \pm 2.66$ \\
\hline
\end{tabular}

${ }^{a} P<0.05$ vs healthy controls. ${ }^{1} \mathrm{MDA}$ : malondialdehyde; SOD: superoxide dismutase; GR: glutathione reductase;GPX: glutathione peroxidase.

significantly in patients. Also, the erythrocyte $\mathrm{Cu}, \mathrm{Zn}-\mathrm{SOD}$, and GR activities increased significantly in the patients compared to the controls. In contrast, the plasma Se-dependent GPX activity in hepatitis $C$ patients was markedly lower.

\section{Correlation of micronutrient concentrations with HCV-RNA levels}

Figures $1 \mathrm{~A}-\mathrm{C}$ shows that there was a significant negative relationship between $\mathrm{Zn}$ contents in erythrocytes/whole blood and HCV-RNA levels (by log) in patients. In plasma, however, no significant correlation was observed. A positive correlation was noted between plasma $\mathrm{Cu}$ and HCV-RNA levels in patients, and an even stronger correlation between the $\mathrm{Cu}$ in erythrocytes/whole blood and HCV-RNA levels (Figures 1D-F).

\section{A}
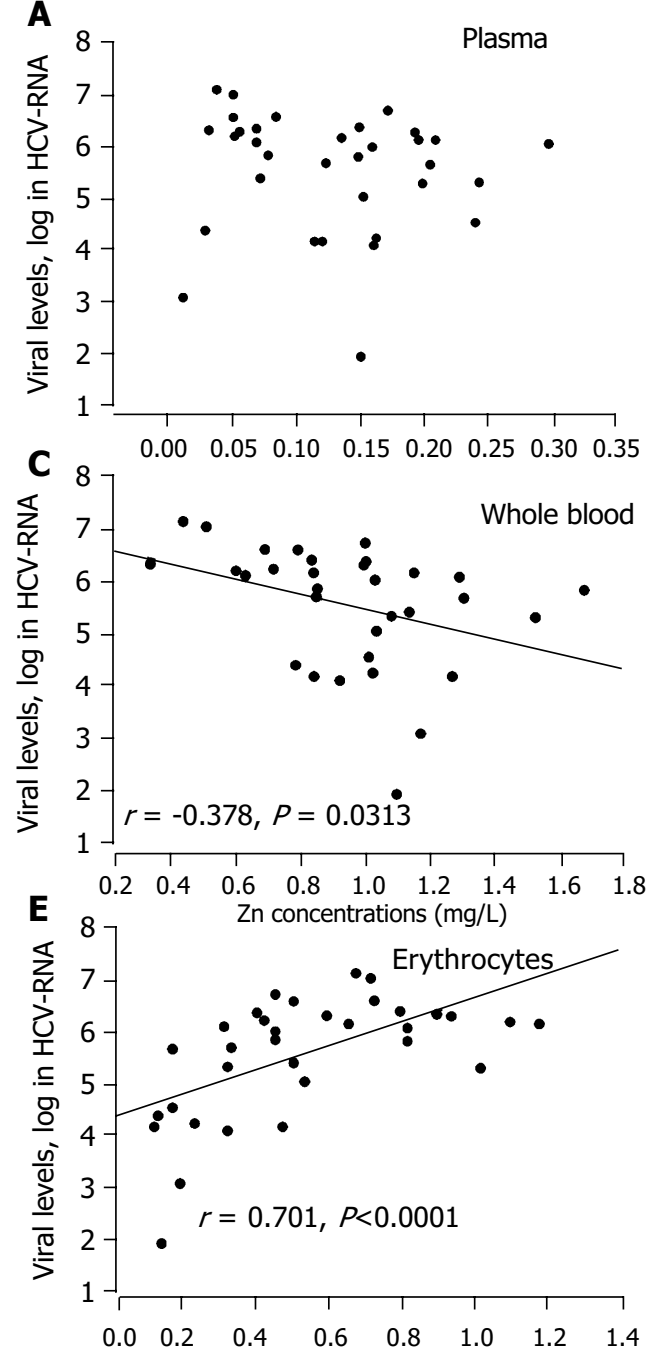

The Se levels in plasma/erythrocytes/whole blood had a statistically significant negative correlation with HCV-RNA levels, whereas a better correlation was found in plasma or whole blood (Figures 1G-I, $r=-0.730,-0.742, P<0.0001$ ).

\section{Relationship between oxidative stress and HCV-RNA levels}

No significant correlation was found between MDA in plasma and HCV-RNA levels ( $P>0.05$, data not presented). However, erythrocyte MDA production was positively correlated with HCV-RNA concentration (Figure 1J, $r=0.629, P<0.0001)$. Additionally, HCV-RNA levels correlated with both erythrocyte GR (Figure $1 \mathrm{~K}, r=0.441$, $P=0.01$ ) and plasma GPX (Figure 1L, $r=-0.675, P<0.0001$ ) activities. The activities of SOD did not correlate with the HCV-RNA levels ( $P>0.05$, data not shown).
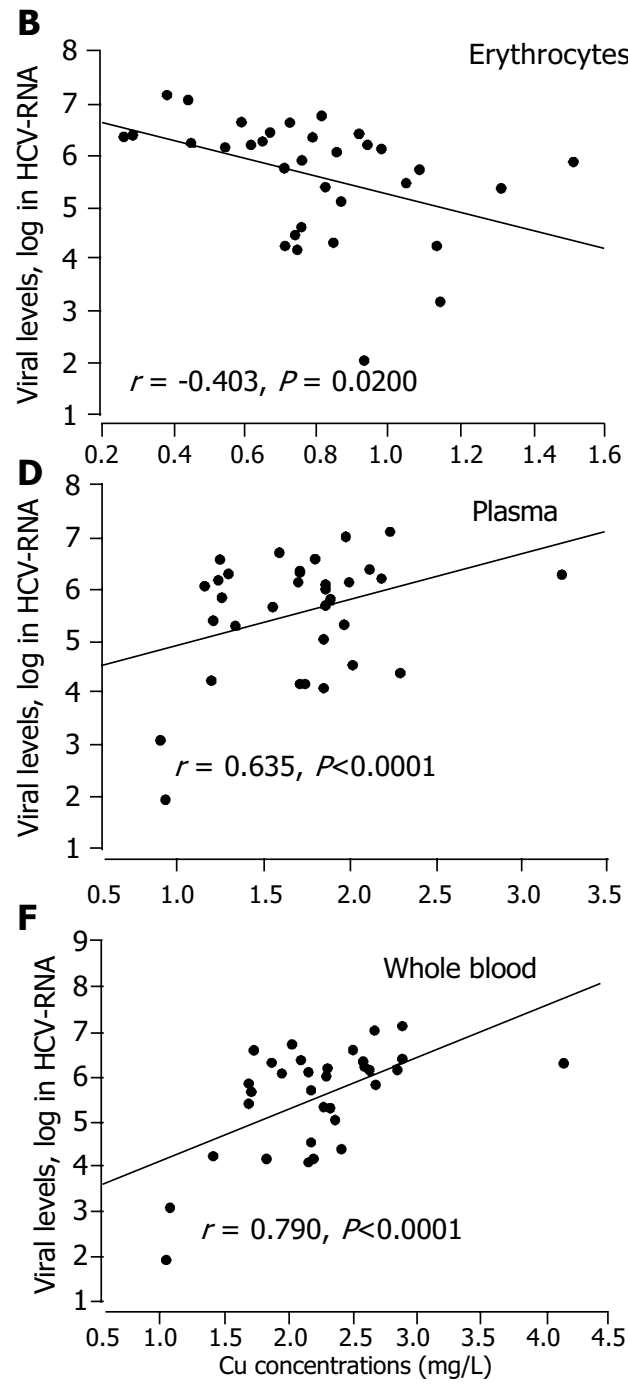

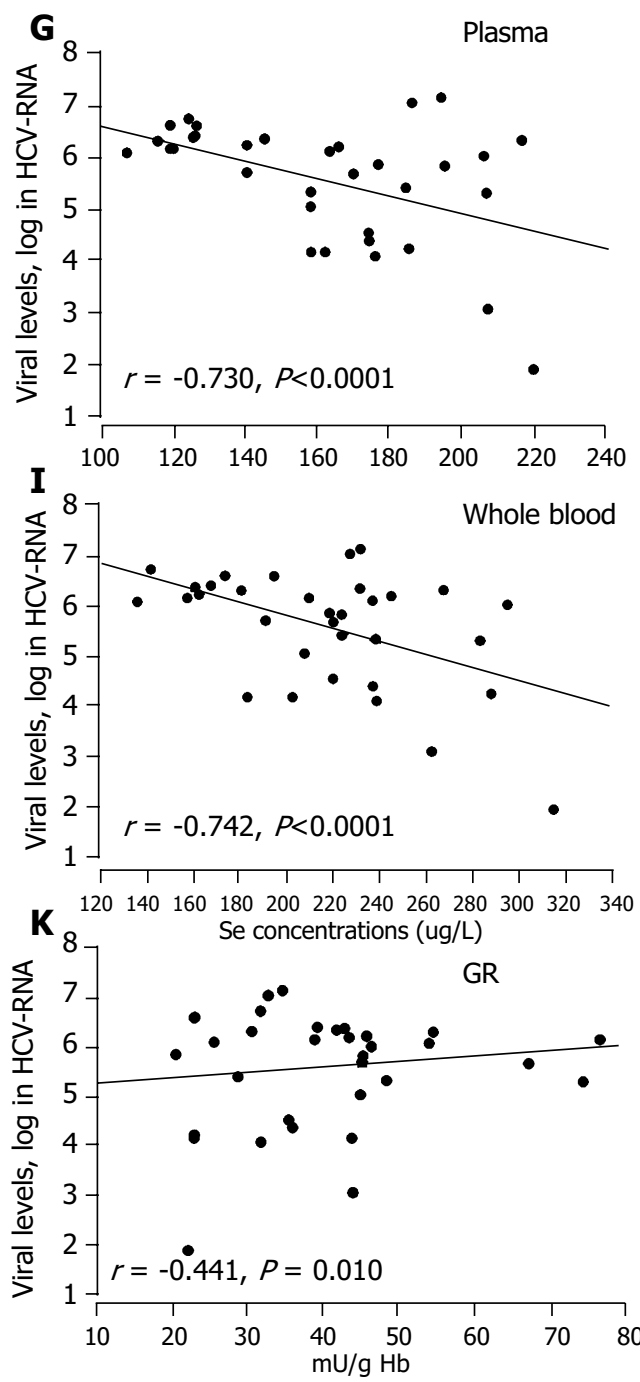

Figure 1 Correlations between viral levels and plasma zinc (A), erythrocytes zinc (B), or whole blood zinc (C), plasma copper (D), erythrocyte copper (E), whole blood copper $(\mathbf{F})$, plasma selenium $(\mathbf{G})$, erythrocyte selenium $(\mathbf{H})$, whole

\section{DISCUSSION}

The purpose of our study was to find the levels of blood micronutrient and oxidative stress in patients with chronic hepatitis $\mathrm{C}$, and to search for linkages between the HCV-RNA levels and micronutrient status, as well as between oxidative stress and the presence of antioxidant enzymes.

The essential micronutrients $(\mathrm{Zn}, \mathrm{Cu}, \mathrm{Fe}$, and $\mathrm{Se})$ might exacerbate liver disease in case of deficiency, imbalance, or toxicity ${ }^{[5,30]}$. They are also linked to the process of oxidation during chronic liver damage ${ }^{[6,7,31]}$. In the present investigation, the levels of $\mathrm{Zn}$ and Se in plasma and erythrocytes of $\mathrm{HCV}$-infected patients decreased significantly compared to healthy subjects. On the contrary, the Cu levels in patients were significantly higher than those in the control group. Nevertheless, alterations of these micronutrients in plasma and erythrocytes varied in different magnitudes.

Decreasing levels of $\mathrm{Zn}$, Se, or increasing Cu levels were also noted in sera of hepatitis cases ${ }^{[31-33]}$. HCV- and HIV-coinfected patients showed markedly lower blood Se levels compared to HIV-infected patients without concomitant HCV infection ${ }^{[34]}$. However, no significant difference in blood $\mathrm{Zn}$ and Se concentrations was observed between chronic
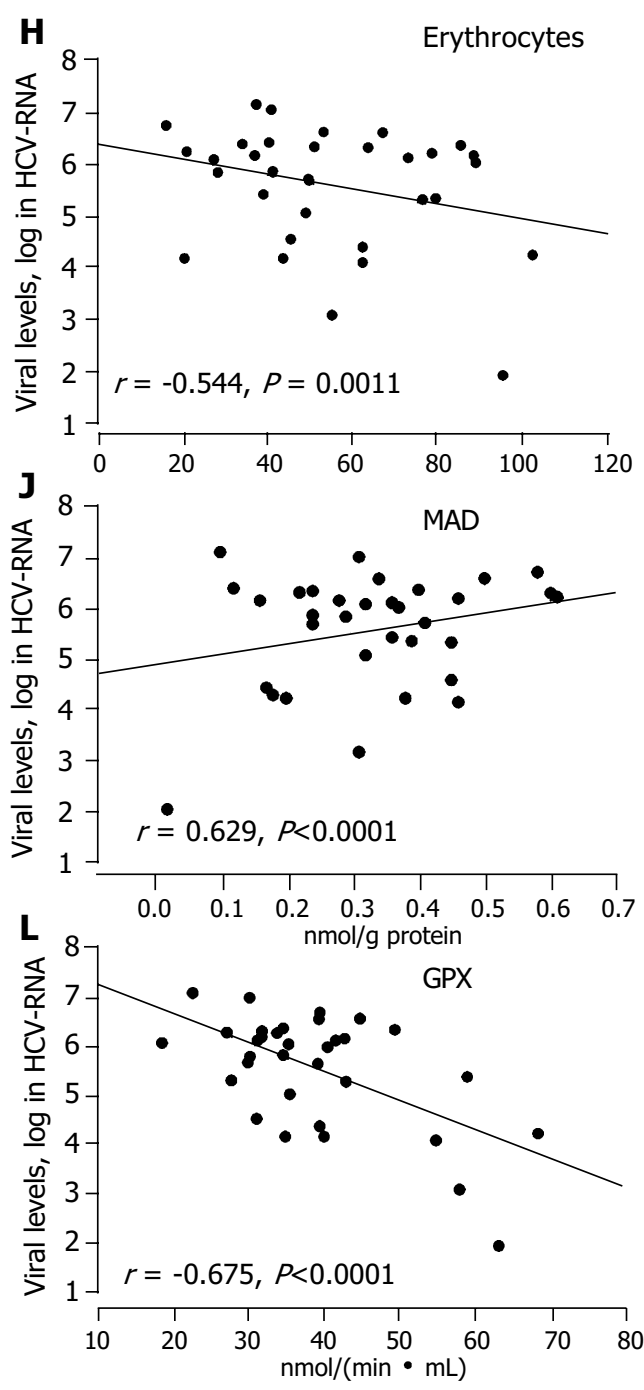

blood selenium (I), erythrocyte MDA (J), GR (K), and plasma GPX activities (L) in chronic hepatitis $\mathrm{C}$ patients.

hepatitis $\mathrm{C}$ patients and controls ${ }^{[35,36]}$. One possible explanation for this discrepancy is that, the subjects in the above two studies could not be distinguished by the type of hepatitis, and patients with hepatitis A-D may have different blood concentrations of $\mathrm{Zn}$ and Se. The present study did not find significantly higher values of erythrocyte $\mathrm{Fe}$ in the patients to coincide with the results in Loguercio et al. ${ }^{[36]}$, whereas some data in the literature show an obvious increase of $\mathrm{Fe}$ contents both in the liver and in the serum of these patients ${ }^{[37,38]}$. Thus, the pretreatment levels of blood Fe might not be a proper marker for the iron status in patients with chronic hepatitis $\mathrm{C}$ infection.

Although the precise causes remain to be elucidated, there is evidence that cytokines might alter the levels of serum trace elements in viral hepatitis ${ }^{[32]}$. It was reported that inflammatory cytokines are higher in $\mathrm{HCV}$-infected individuals than in normal individuals ${ }^{[39,40]}$. Increased $\mathrm{Cu}$ levels might result from inflammatory responses ${ }^{[32]}$. Therefore, the present results suggest that changes of $\mathrm{Zn}$, $\mathrm{Cu}$, and Se levels in plasma and erythrocytes of patients with chronic hepatitis $\mathrm{C}$ are directly related to the pathology developed in the liver. 
ROS plays a crucial role in the induction and progression of liver disease, and are involved in the transcription and activation of a large series of cytokines that could induce production of ROS. Some studies indicate that treatment of high serum Se and $\mathrm{Zn}$ levels leads to reduction of inflammatory reaction in hepatitis patients ${ }^{[41,42]}$. In addition to the anti-inflammatory reaction, Se or $\mathrm{Zn}$ has antioxidant and immuno-modulatory effects ${ }^{[3-45]}$. Copper is also associated with the inflammatory response and oxidative stress ${ }^{[46,47]}$. In the present study, decreased activity of Se-dependent GPX and increased $\mathrm{Cu}, \mathrm{Zn}-\mathrm{SOD}$, and GR activities either in plasma or in erythrocytes suggest that anti-oxidative capability is limited during circulation. The presence of significant increase in MDA levels also indicates a possible oxidative insult in these patients. Liver cirrhosis induces a significant decrease in Se and $\mathrm{Zn}$ levels, another indication of presence of oxidative stress ${ }^{[3]]}$. The levels of MDA have been correlated with the severity of chronic hepatitis ${ }^{[5]}$. There is evidence that the production of free radicals increases while anti-oxidant defense decreases significantly in all types of liver damage ${ }^{[--9]}$. Therefore, supportive nutrients, $\mathrm{Zn}, \mathrm{Cu}$, and $\mathrm{Se}$, and oxidative stress might be sensitive indicators for the degree of liver injuries and the sustained response to therapy in chronic hepatitis $\mathrm{C}$ patients.

The outcome of HCV infection is also thought to depend on the balance between the rate of viral replication, rapidity, and specificity and the effectiveness of the host immune response. Few studies have focused on the relationship between circulating pool of these immune-regulated micronutrients and HCV-RNA contents. Our present results suggest that there is a markedly negative relationship between HCV-RNA titer (in log) and either erythrocyte or whole blood $\mathrm{Zn}$ concentrations. Similarly, the inverse correlations between HCV-RNA and blood Se levels observed in this study suggest that significant higher viral loads are correlated with lower blood $\mathrm{Zn}$ and Se levels in HCV-infected patients.

In addition, higher levels of blood $\mathrm{Cu}$ are markedly correlated with higher HCV-RNA concentrations. Little is known about the possible regulatory mechanism of micronutrients in the pathogenesis of HCV infection. However, these nutrients are known to assist in immunemediated response and involve in the alteration of virus genomes $^{[5,27,45,48]}$. It is suggested that the distribution of $\mathrm{Zn}$, $\mathrm{Se}$, and $\mathrm{Cu}$ might affect sustained response to therapy in patients with chronic hepatitis C. Therefore, these micronutrients may be involved in multiple points in the immune pathogenesis of HCV infection that is essential for viral clearance.

The oxidative stress is high in hepatitis patients, and there are significant correlations among HCV-RNA and erythrocyte MDA, erythrocyte GR and plasma GPX activities. Zhang et al. ${ }^{[26]}$, reported that Se-dependent GPX modules are encoded in a number of RNA viruses, including HIV-1, HCV, Coxsackie's virus B3, and HIV-2 virus. A HCV-encoded GPX gene might demonstrate that oxidant stress is associated with HCV disease progression. In HIV-infected patients, the decline in Se levels is greater than that in those with HCV co-infection ${ }^{[34]}$. Se deficiency increases the virulence of CVB3 infection, which is encoded by the GPX gene within Keshan disease's cofactor ${ }^{[26,49]}$. It has been proposed that Se-dependent GPX participates directly in immune cytotoxicity, enabling neutrophils and macrophages to complete intracellular lysis of phagocytosed cells. In previous investigations, an inverse relationship between Se level and HBV infection incidence was found ${ }^{[50]}$. $\mathrm{Zn}$ has also been studied for its antiviral effect against HIV, rhinovirus, and herpes virus ${ }^{[24]}$. Moreover, $\mathrm{Zn}$ supplementation enhances the response to interferon therapy in chronic hepatitis $\mathrm{C}$ patients ${ }^{[25]} \mathrm{Zn}$ is necessary for the dimerization of interferon, which activates the interferon receptor ${ }^{[51]}$. It is apparent that erythrocyte and plasma $\mathrm{Zn}$, $\mathrm{Se}$, and $\mathrm{Cu}$ levels and oxidative stress are associated with HCV-RNA levels.

In conclusion, the distribution of $\mathrm{Zn}, \mathrm{Cu}$, Se levels and MDA product, GPX and GR activities in blood may be an additional host-specific parameter (outside of predictive viral factors) with a predictive value for the responsiveness of patients to interferon/ribavirin therapy. Furthermore, these results may be affected by immunocytokines as a host-defense system during $\mathrm{HCV}$ infection.

\section{ACKNOWLEDGMENT}

Great appreciation is extended to Miss Anna Hsu of Oregon State University for the English editing of the manuscript.

\section{REFERENCES}

1 Beisel WR. Single nutrients and immunity. Am J Clin Nutr 1982; 35(2 Suppl): 417-468

2 Evans GW. Zinc and its deficiency diseases. Clin Physiol Biochem 1986; 4: 94-98

3 Bray TM, Bettger WJ. The physiological role of zinc as an antioxidant. Free Rad Biol Med 1990; 8: 281-291

4 Bhaskaram P. Micronutrient malnutrition, infection, and immunity: an overview. Nutr Rev 2002; 60: S40-S45

5 Ozcelik D, Ozaras R, Gurel Z, Uzun H, Aydin S. Coppermediated oxidative stress in rat liver. Biol Trace Elem Res 2003; 96: $209-215$

6 Halliwell B, Gutteridge JMC. Role of free radicals and catalytic metal ions in human disease: an overview. Methods Enzymol 1990; 186: 1-85

7 Peterhans E. Reactive oxygen species and nitric oxide in viral diseases. Biol Trace Elem Res 1997; 56: 107-116

8 Jain SK, Pemberton PW, Smith A, McMahon RF, Burrows PC, Aboutwerat A, Warnes TW. Oxidative stress in chronic hepatitis C: not just a feature of late stage disease. $J$ Hepatol 2002; 36: 805-811

9 Loguercio C, Federico A. Oxidative stress in viral and alcoholic hepatitis. Free Radic Biol Med 2003; 34: 1-10

10 Toubi E, Kessel A, Goldstein L, Slobodin G, Sabo E, Shmuel Z, Zuckerman E. Enhanced peripheral T-cell apoptosis in chronic hepatitis $C$ virus infection: association with liver disease severity. J Hepatol 2001; 35: 774-780

11 National institutes of health consensus development conference panel statement: management of hepatitis C. Hepatology 1997; 15: 1-41

12 McHutchison JG, Gordon SC, Schiff ER, Shiffman ML, Lee WM, Rustgi VK, Goodman ZD, Ling MH, Cort S, Albrecht JK. Interferon alfa-2b alone or in combination with ribavirin as initial treatment for chronic hepatitis C. N Engl J Med 1998; 339: 1485-1492

13 Poynard T, Leroy V, Cohard M, Thevenot T, Mathurin P, Opolon P, Zarski JP. Meta-analysis of interferon randomized trials in the treatment of viral hepatitis: effects of dose and duration. Hepatology 1996; 24: 778-789 
14 Poynard T, Marcellin P, Lee SS, Niederau C, Minuk GS, Ideo G, Bain V, Heathcote J, Zeuzem S, Trepo C, Albrecht J. Randomised trial of interferon alpha $2 \mathrm{~b}$ plus ribavirin for 48 wk or for $24 \mathrm{wk}$ virus interferon with hepatitis $C$ virus. Lancet 1998; 352: 1426-1432

15 Thevenot T, Regimbeau C, Ratziu V, Leroy V, Opolon P, Poynard T. Meta-analysis of interferon randomized trials in the treatment of viral hepatitis $C$ in naïve patients. J Viral Hepat 1999; 8: 48-62

16 Hoofnagle JH. Management of hepatitis C: current and future perspectives. J Hepatol 1999; 31(Suppl 1): 264-268

17 Neuman MG, Benhamou JP, Malkiewicz IM, Akremi R, Shear $\mathrm{NH}$, Asselah T, Ibrahim A, Boyer N, Martinot-Peignoux M, Jacobson-Brown P, Katz GG, Le Breton V, Le Guludee G, Suneja A, Marcellin P. Cytokines as predictors for sustained response and as markers for immunomodulation in patients with chronic hepatitis C. Clin Biochem 2001; 34: 173-182

18 Ho SB, Nguyen H, Tetrick LL, Opitz GA, Basara ML, Dieperink E. Influence of psychiatric diagnoses on interferona treatment for chronic hepatitis $C$ in a veteran population. Am J Gastroenterol 2001; 96: 157-164

19 Kumar D, Wallington-Beddoe C, George J, Lin R, Samarasinghe D, Liddle C, Farrell GC. Effectiveness of interferon alfa-2b/ ribavirin combination therapy for chronic hepatitis $\mathrm{C}$ in a clinic setting. Med J Aust 2003; 178: 267-271

20 Van Thiel DH, Friedlander L, Fagiuoli S, Wright HI, Irish W, Gavaler JS. Response to interferon therapy is influenced by the iron content of the liver. J Hepatol 1994; 20: 410-415

21 Olynyk JK, Reddy KR, Di Bisceglie AM, Jeffers LJ, Parker TI, Radick JL, Schiff ER, Bacon BR. Hepatic iron concentration as a predictor of response to interferon á therapy in chronic hepatitis C. Gastroenterology 1995; 108: 1104-1109

22 Kageyama F, Kobayashi Y, Murohisa G, Shimizu E, Suzuki F, Kikuyama M, Souda K, Kawasaki T, Nakamura H. Failure to respond to interferon- $\alpha 2 \mathrm{a}$ therapy is associated with increased hepatic iron levels in patients with chronic hepatitis C. Biol Trace Elem Res 1998; 64: 185-196

23 Carlo C, Daniela P, Giancarlo C. Iron depletion and response to interferon in chronic hepatitis C. Hepatogastroenterology 2003; 50: $1467-1471$

24 Nagamine T, Takagi H, Takayma H, Kojima A, Kakizaki S, Mori M, Nakajima K. Preliminary study of combination therapy with interferon- $\alpha$ and zinc in chronic hepatitis $C$ patients with genotype 1b. Biol Trace Elem Res 2000; 75: 53-63

25 Takagi H, Nagamine T, Abe T, Takayama H, Sato K, Otsuka T, Kakizaki S, Hashimoto Y, Matsumoto T, Kojima A, Takezawa J, Suzuki K, Sato S, Mori M. Zinc supplementation enhances the response to interferon therapy in patients with chronic hepatitis C. J Viral Hepatol 2001; 8: 367-371

26 Zhang W, Ramanathan CS, Nadimpalli RG, Bhat AA, Cox AG, Taylor EW. Selenium-dependent glutathione peroxidase modules encoded by RNA viruses. Biol Trace Elem Res 1999; 70: $97-116$

27 Sabbioni E, Blanch N, Baricevic K, Serra MA. Effects of trace metal compounds on HIV-1 reverse transcriptase. An in vitro study. Biol Trace Elem Res 1999; 68: 107-119

28 Guo CH, Huang CJ, Chiou YL, Hsu GSW. Alteration of trace element distribution and testis ACE activity in mice with high peritoneal aluminum. Biol Trace Elem Res 2002; 86: 145-158

29 Richard MJ, Portal B, Meo J, Coudray C, Hadjian A, Favier A. Malondialdehyde kit evaluated for determining plasma and lipoprotein fractions that react with thiobarbituric acid. Clin Chem 1992; 38: 704-709

30 Buck WB, Ewan RC. Toxicology and adverse effects of mineral imbalance. Clin Toxicol 1973; 6: 459-485

31 Pramoolsinsap C, Promvanit N, Komindr S, Lerdverasirikul $\mathrm{P}$, Srianujata S. Serum trace metals in chronic viral hepatitis and hepatocellular carcinoma in Thailand. J Gastroenterol 1994; 29: 610-615

32 Kalkan A, Bulut V, Avci S, Celik I, Bingol NK. Trace ele- ments in viral hepatitis. J Trace Elem Med Biol 2002; 16: 227-230

33 Czuczejko J, Zachara BA, Staubach-Topczewska E, Halota $\mathrm{W}$, Kedziora J. Selenium, glutathione and glutathione peroxidase in blood of patients with chronic liver diseases. Acta Biochim Polon 2003; 50: 1147-1154

34 Look MP, Rockstroh JK, Rao GS, Kreuzer KA, Barton S, Lemoch H, Sudhop T, Hoch J, Stockinger K, Spengler U, Sauerbruch T. Serum selenium, plasma glutathione (GSH) and erythrocyte glutathione peroxidase (GSH-Px)-levels in asymptomatic versus symptomatic human immunodeficiency virus-1 (HIV-1)-infection. Eur I Clin Nutr 1997; 51: 266-272

35 Loguercio C, de Girolamo V, Federico A, Feng SL, Cataldi V, Del Vecchio Blanco C, Gialanella G. Trace elements and chronic liver diseases. J Trace Elem Med Biol 1997; 11: 158-161

36 Loguercio C, de Girolamo V, Federico A, Feng SL, Crafa E, Cataldi V, Gialanella G, Moro R, del Vecchio BC. Relationship of blood trace elements to liver damage, nutritional status, and oxidative stress in chronic nonalcoholic liver disease. Biol Trace Elem Res 2001; 81: 245-254

37 Sikorska K, Stalke P, Lakomy EA, Michalska Z, WitczakMalinowska K, Stolarczyk J. Disturbances of iron metabolism in chronic liver diseases. Med Sci Monit 2003; 9(Suppl 3): 64-67

38 Metwally MA, Zein CO, Zein NN. Clinical significance of hepatic iron deposition and serum iron values in patients with chronic hepatitis C infection. Am J Gastroenterol 2004; 99: 286-291

39 Malaguarnera M, Di Fazio I, Romeo MA, Restuccia S, Laurino A, Trovato BA. Elevation of IL6 levels in patients with chronic hepatitis due to hepatitis C virus. J Gastroenterol 1997; 32: 211-215

40 Neuman MG, Benhamou JP, Martinot M, Boyer N, Shear $\mathrm{NH}$, Malkiewicz I, Katz GG, Suneja A, Singh S, Marcellin P. Predictors of sustained response to alpha interferon therapy in chronic hepatitis C. Clin Biochem 1999; 32: 537-545

41 Sartori M, Andorno S, Rigamonti C, Boldorini R. Chronic hepatitis $C$ treated with phlebotomy alone: biochemical and histological outcome. Dig Liver Dis 2001; 33: 157-162

42 Selimoglu MA, Aydogdu S, Unal F, Yuce G, Yagci RV. Serum zinc status in chronic hepatitis B and its relationship to liver histology and treatment results. Pediat Intern 2001; 43: 396-399

43 Tanasescu C, Baldescu R, Chirulescu Z. Interdependence between $\mathrm{Zn}$ and $\mathrm{Cu}$ serum concentrations and serum immunoglobins ( $\operatorname{Ig} \mathrm{A}, \operatorname{IgM}, \operatorname{IgG})$ in liver diseases. Rom J Intern Med 1996; 34: 217-224

44 Takagi H, Nagamine T, Abe T, Takayama H, Sato K, Otsuka T, Kakizaki S, Hashimoto Y, Matsumoto T, Kojima A, Takezawa J, Suzuki K, Sato S, Mori M. Zinc supplementation enhances the response to interferon therapy in patients with chronic hepatitis C. J Viral Hepatol 2001; 8: 367-371

45 Cunningham-Rumdles S, Ahrn S, Abuav-Nussbaum R, Dnistrian A. Development of immunocompetence: Role of micronutrients and microorganisms. Nutr Rev 2002; 60: S68-S72

46 Fisher AE, Naughton DP. Vitamin C contributes to inflammation via radical generating mechanisms: a cautionary note. Med Hypotheses 2003; 61: 657-660

47 Klein D, Lichtmannegger J, Finckh M, Summer KH. Gene expression in the liver of Long-Evans cinnamon rats during the development of hepatitis. Arch Toxicol 2003; 77: 568-575

48 Taylor EW, Nadimpalli RG, Ramanathan CS. Genomic structures of viral agents in relation to the biosynthesis of selenoproteins. Biol Trace Elem Res 1997; 56: 63-91

49 Beck MA, Shi Q, Morris VC, Levander OA. Rapid genomic evolution of a non-virulent Coxackievirus B3 in seleniumdeficient mice results in selection of identical virulent isolates. Nature Med 1995; 1: 433-436

50 Yu SY, Zhu YJ, Li WG. Protective role of selenium against hepatitis B virus and primary liver cancer in Qidong. Biol Trace Elem Res 1997; 56: 117-124

51 Radhakrishnan R, Walter LJ, Hruza A, Reichert P, Trotta PP, Nagabhushan TL, Walter MR. Zinc mediated dimmer of human interferon-alpha $2 \mathrm{~b}$ revealed by $\mathrm{X}$-ray crystallography. Structure 1996; 4: 1453-1463 